\title{
Relationship of Blood Groups (ABO \& Rhesus) and Breast Cancer in Bangladesh
}

\author{
Ghulam Mostafa Khan ${ }^{1}$, Md. Rahmatullah ${ }^{2}$, Ishita Mostafa ${ }^{3}$ \\ Received: May 5, 2013 Accepted: June 5, 2013
}

\begin{abstract}
Background: The association of blood groups with breast cancer in our country is not fully established elaborately and large scale studies have not been carried out till now. Therefore this study was designed to find out the possible relationship of different blood groups with breast cancer. Objective: To determine the relationship of various types of breast cancer with $A B O$ and Rh blood groups among the female patients of our people. Materials and Methods: This cross sectional study was conducted in the cancer unit of Delta Medical College and Hospital, Dhaka from January 2011 to February 2013. After proper and ethical consideration total 112 female patients with breast cancer were included in this study. Various factors like age, family history, metastasis, type of cancer were considered in this study. The blood groups of the patients were done by standard $A B O$ and Rh typing methods (Forward \& Reverse grouping by test tube method). Results: Among 112 breast cancer patients of our country, ductal breast cancer was found in 108 (96.42\%) subjects, distant metastasis was found in 93 (86.9\%) cases and positive family history in 70 (62.50\%) subjects. Conclusion: Ductal type of breast cancer with positive family history and distant metastasis is common in different blood groups in our country.
\end{abstract}

Key words: Breast cancer; $A B O$ \& Rhesus blood group; Metastasis

J Enam Med Col 2014; 4(2): 106-109

\section{Introduction}

Breast cancer is the one of the fatal malignant tumors and the important cause of mortality due to cancer in females. Many factors such as genetic factors, hormone consumption, lactation, late menopause, diet, radiation, alcohol consumption and exogenous estrogen intake have important role in the occurrence of breast cancer. ${ }^{1-4}$ The blood group type is one of the genetic factors which affect the risk of different cancers. ABO blood group genes are mapped at chromosome $9 \mathrm{q}$, in which the genetic alteration is common in many cancers. ${ }^{5}$

Studies of associations between tumor outcomes and the patient's ABO blood groups have shown increased relative risks for some blood groups. There is however evidence that $\mathrm{ABO}$ blood groups may have importance, since the antigens of blood groups seem to have a significant biological role in the immunological system, thereby promoting the development of some tumors, including breast cancer. ${ }^{6}$ A history of breast cancer in first degree relatives was also found to be strongly associated with Rhesus negative blood type. Many studies have been carried out in different countries in different races to analyze blood factors and their possible association with breast cancer. Unfortunately, no appreciable research has been done so far in our country.

1. Professor, Department of Transfusion Medicine, Enam Medical College \& Hospital, Savar, Dhaka

2. Assistant Professor, Department of Community Medicine, Delta Medical College, Mirpur, Dhaka

3. Lecturer, Department of Surgery, Saphena Women's Dental College, Dhaka

Correspondence Ghulam Mostafa Khan, Email: gmkksa@hotmail.com 


\section{Materials and Methods}

This cross sectional study was conducted in the cancer unit of Delta Medical College Hospital, Dhaka during the period of January 2011 to February 2013. After proper and ethical consideration total 112 female patients with breast cancer were included in this study. These patients had similar demographic, clinical, surgical, laboratory, and follow up data. This group of patients came from different parts of the country, so they are representatives of women among the general population. Blood specimens were collected from these women during their preoperative control and follow-up in the cancer unit. Factors like family history, clinical/surgical findings, blood group, histological findings (including type of cancer, degree of malignancy) and the presence of nodal and/or distant metastases were investigated. Both $\mathrm{ABO}$ and $\mathrm{Rh}$ blood groups were done by standard methods (Forward \& Reverse grouping by test tube method).

\section{Results}

In the present study ductal breast cancer was found more frequently $(96.42 \%)$ than lobular type of breast cancer (3.58\%) (Table I). Family history was positive in most of the breast cancer patients $(62.50 \%)$ (Table II). In this study, distant metastasis was found in $84.82 \%$ of the breast cancer patients (Table III). As only $\mathrm{Rh}$ blood group is concerned, $\mathrm{Rh}(+)$ patients with breast cancer were found to have increased frequency of metastasis (86.9\%) (Table IV). In this study there was no subject with $\mathrm{AB}(-)$ group.

Table I: Blood groups and histological types of breast cancer

\begin{tabular}{|c|c|c|}
\hline Blood Groups & Ductal type & Lobular type \\
\hline $\mathrm{A}+$ & 35 & 1 \\
\hline $\mathrm{A}-$ & 3 & 0 \\
\hline $\mathrm{B}+$ & 33 & 0 \\
\hline $\mathrm{B}-$ & 1 & 0 \\
\hline $\mathrm{AB}+$ & 14 & 1 \\
\hline $\mathrm{AB}-$ & 0 & 0 \\
\hline $\mathrm{O}+$ & 21 & 2 \\
\hline O- & 1 & 0 \\
\hline Total & $108(96.42 \%)$ & $4(3.58 \%)$ \\
\hline
\end{tabular}

Table II: Family history of breast cancer patients

\begin{tabular}{|c|c|c|}
\hline Blood Groups & \multicolumn{2}{|c|}{ Family history } \\
\hline A+ & Positive & Negative \\
\hline A- & 23 & 13 \\
B+ & 2 & 1 \\
\hline B- & 21 & 12 \\
\hline AB+ & 1 & 0 \\
\hline AB- & 10 & 5 \\
O+ & 12 & 0 \\
\hline O- & 1 & 11 \\
\hline Total & $70(62.50 \%)$ & 0 \\
\hline
\end{tabular}

Table III: Frequency of metastasis in study subjects $(n=112)$

\begin{tabular}{|c|c|c|}
\hline Blood Groups & \multicolumn{2}{|c|}{ Metastasis } \\
\hline A+ & Yes & No \\
\hline A- & 34 & 2 \\
\hline B+ & 2 & 1 \\
\hline B- & 28 & 5 \\
\hline AB+ & 13 & 1 \\
\hline AB- & 0 & 2 \\
\hline O+ & 18 & 0 \\
\hline O- & 0 & 5 \\
\hline Total & $95(84.82 \%)$ & 1 \\
\hline
\end{tabular}

Table IV: Frequency of metastasis in breast cancer patients with $\mathrm{Rh}+$ and $\mathrm{Rh}$ - blood groups

\begin{tabular}{|c|c|c|c|}
\hline Blood Groups & \multicolumn{3}{|c|}{ Metastasis } \\
\cline { 2 - 4 } & Yes & No & Total \\
\hline Rh+ & $93(86.9 \%)$ & $14(13.1 \%)$ & 107 \\
Rh- & $2(40 \%)$ & $3(60 \%)$ & 5 \\
Total & 95 & 17 & 112 \\
\hline
\end{tabular}

\section{Discussion}

The role of genetic factors in the development of cancer is widely accepted. Alexander in 1921 reported that patients with blood group $\mathrm{B}$ and $\mathrm{AB}$ were more vulnerable to develop malignancy which can be more aggressive than neoplasms occurring in patients with other blood groups. ${ }^{7}$ Association between blood group A and gastric cancer has also 
been found. ${ }^{8}$ This was subsequently confirmed by other investigators, which showed a further association between blood group A and pernicious anemia. ${ }^{9}$ Pandey et al showed an increased frequency of carcinoma of the gall bladder in blood groups $\mathrm{A}$ and $\mathrm{AB} .{ }^{10}$ Regarding breast cancer, Vogel reported that $\mathrm{ABO}$ blood groups can potentially influence the prognosis. ${ }^{11}$ ABO blood groups have been recognized as predisposing or prognostic factor in breast cancer by some other researchers also. ${ }^{12-15}$ It has been reported that A blood group is more frequent in patients with breast cancer in comparison with O blood group. ${ }^{16}$ One study with 368 breast cancer patients in India found high frequency of blood group O (34.92\%), followed by B (28.57\%), A $(24.60 \%)$ and $\mathrm{AB}(11.9 \%) .{ }^{14}$ Another study by Akammu et al ${ }^{17}$ shows there is a negative relation between $\mathrm{Rh} \mathrm{D}$ antigen heritage and the diffusion of breast cancer and the Rh $\mathrm{D}$ phenotype could be conservative against breast cancer. A study performed among 1001 patients with invasive breast cancer in 1995 by Holdsworth et al ${ }^{18}$ shows the B or $\mathrm{AB}$ blood groups to be a prognostic factor, especially in patients who are at high risk for early mortality or tumor recurrence with $\mathrm{AB}$ blood group showing a relation with higher local occurrence. A study performed by Jalali-Naduoshan et al in Zanjan, Iran in 2002 showed that there is a relationship between the B-antigen of the blood group and the poor prognosis of the breast cancer. ${ }^{19}$ A study in Uruguay reported that among women with $\mathrm{Rh}$ positive blood, those with a family history of breast cancer, type A blood group subjects were found to have more frequency of breast cancer than subjects with other blood groups. ${ }^{20}$

In this study ductal type of breast cancer was found in 108 patients $(96.42 \%)$ and distant metastasis was found in $93(86.9 \%)$ cases. Seventy patients $(62.50 \%)$ had positive family history of breast cancer. However, further studies with larger number of patients are needed to clearly establish the association of $\mathrm{ABO}$ and $\mathrm{Rh}$ blood groups with the breast cancer in female of our country.

\section{References}

1. Lango D. Oncology and hematology. In: Kasper DL, Braunwald E, Fauci AS, Hauser SL, Longo DL, Jameson JL (eds). Harrison's principles of internal medicine. 15th edn. New York: McGraw-Hill, 2001: 491-653.
2. Lester SC. The breast. In: Kumar V, Abbas AK, Fausto N, Aster JC (eds). Robbins and Cotran Pathologic basis of disease. 8th edn. Philadelphia: Saunders, 2010: 1065-1095.

3. Dark GG, Razak ARA. Oncology. In: Colledge NR, Walker BR, Ralston SH. Davidson's Principles and practice of Medicine. 21st edn. Edinburgh: Elsevier, 2010: 255-277.

4. Solid Tumors. In: Griggs J, Desch CH (eds). Cecil essential of medicine. 5th edn. Philadelphia: Saunders, 2004: 525-537.

5. $\mathrm{Hu} \mathrm{N}$, Roth MJ, Polymeropolous M, Tang ZZ, EmmertBuck MR, Wanf QH. Identification of novel regions of allelic loss from a genomewide scan of esophageal squamous cell carcinoma in a high risk Chinese population. Genes Chromosomes Cancer 2000; 27: $217-228$.

6. Costantini M, Fassio T, Canobbio L, Landucci M, Resasco M, Boccardo F. Role of blood groups as prognostic factors in primary breast cancer. Oncology 1990; 47: 308-312. doi:10.1159/000226839.

7. Alexander W. An inquiry into distribution of the blood groups in patients suffering from malignant disease. Brit J Exp Path 1921; 2: 66.

8. Aird I, Bentall HH, Roberts JA. A relationship between cancer of stomach and the ABO blood groups. Br Med J. 1953; 4814: 799-801. doi: 10.1136/bmj.1.4814.799.

9. Hoskins LC, Loux HA, Britten A, Zamcheck N. Distribution of $\mathrm{ABO}$ blood groups in patients with pernicious anemia, gastric carcinoma and gastric carcinoma associated with pernicious anemia. N Engl J Med 1965; 273: 633-637.

10. Pandey M, Gautam A, Shukla VK. ABO and Rh blood groups in patients with cholelithiasis and carcinoma of the gallbladder. BMJ 1995; 310: 1639.

11. Vogel F. Controversy in human genetics. ABO blood groups and disease. Am J Hum Genet 1970; 22: $464-475$.

12. Anderson DE. Some characteristics of familial breast cancer. Cancer 1971; 28: 1500-1504. doi: 10.1002/10970142(197112)28:6<1500::AID-CNCR2820280623> 3.0.CO;2-D.

13. Easton DF. Familial risks of breast cancer. Breast Cancer Res 2002; 4: 179-181. doi: 10.1186/bcr448.

14. Majupuria KC, Gupta SR, Gupta LC. The study of ABO blood groups and relationship with breast cancer. Indian J Cancer 1966; 3: 182-183. 
15. Skolnick MH, Thompson EA, Bishop DT, Cannon LA. Possible linkage of a breast cancer susceptibility locus to the ABO locus: sensitivity of LOD scores to a single new recombinant observation. Genet Epidemiol 1984; 1: 363-373. doi: 10.1002/gepi.1370010408.

16. Luck G, Haber ND, Adams P. Blood type and cancer 2005; 14(4): 308-312.

17. Akammu AS, Durusinmi-El FAA, Emuveyan EE, AbdolKaareem FB, Vgwoude CS, Dawotola DA. The association between cancer of the breast and $\mathrm{ABO}$ and Rhesus D antigen phenotypes in Lagos, Nigeria central study. Nigerian J of Clinical Practice 2002; 5(2): 81-86.
18. Holdsworth WJ, Benson EA, Clayden AD. Blood group as prognostic indicator in breast cancer. BMJ 1995; 290(6469): 671-673.

19. Jalali-Nadoshan MR, Hashemi M, Valac N. Role of ABO blood groups as prognostic factors in primary breast cancer. Journal of Zanjan University 2002; 38(10): 21-27.

20. Ronco AL, Stoll M, Stefani E, Maisonneuve JE, Mendoza BA, Deneo-Pellegrini H. Rh factor, family history and risk of breast cancer: a case-control study in Uruguay. Cancer Detection and Prevention 2009; 32(4): 277-285. 